July 2017

\title{
Shaping our literate lives: Examining the role of literacy experiences in shaping positive literacy identities of doctoral students
}

Christy M. Howard

East Carolina University, howardch14@ecu.edu

Melissa Adams-Budde

Joy Myers

Grant Jolliff

Follow this and additional works at: https://digitalcommons.georgiasouthern.edu/ij-sotl

\section{Recommended Citation}

Howard, Christy M.; Adams-Budde, Melissa; Myers, Joy; and Jolliff, Grant (2017) "Shaping our literate lives: Examining the role of literacy experiences in shaping positive literacy identities of doctoral students," International Journal for the Scholarship of Teaching and Learning: Vol. 11: No. 2, Article 8. Available at: https://doi.org/10.20429/ijsotl.2017.110208 


\title{
Shaping our literate lives: Examining the role of literacy experiences in shaping positive literacy identities of doctoral students
}

\author{
Abstract \\ The purpose of this study was to examine the ways in which literacy histories and present literacy \\ experiences of doctoral students shaped their literacy identities. Data were collected through surveys, \\ interviews, and visual identity representations. This paper focuses on the literacy stories of two doctoral \\ students with positive literacy identities. Findings suggest that participants valued literacy as a social \\ learning experience from an early age through higher education. These social experiences with reading \\ and writing can take many forms and can be embraced in various home and school contexts. Additionally, \\ these findings highlight the need for schools to create and nurture such experiences across all grade \\ levels, through multiple forums, which may lead to positive literacy identities.
}

\section{Keywords}

literacy identity, doctoral students, literacy history, social learning

\section{Creative Commons License}

c) (i) $९$

This work is licensed under a Creative Commons Attribution-Noncommercial-No Derivative Works 4.0 License. 


\title{
Shaping our Literate Lives: Examining the Role of Literacy Experiences in Shaping Positive Literacy Identities
}

\author{
Christy M. Howard', Melissa Adams-Budde'2, Joy Myers 3 , Grant Jolliff ${ }^{4}$ \\ 'College of Education, East Carolina University, Greenville, NC 27858, USA \\ ${ }^{2}$ College of Education and Social Work, West Chester University, West Chester, PA 19383, USA \\ ${ }^{3}$ Early, Elementary, \& Reading Education Department, James Madison University, Harrisonburg, VA 22807, USA \\ ${ }^{4}$ Admissions Office, University of North Carolina-Greensboro, Greensboro, NC 274 I2, USA
}

(Received 25 July 2016; Accepted 6 February 2017)

\begin{abstract}
The purpose of this study was to examine the ways in which literacy histories and present literacy experiences of doctoral students shaped their literacy identities. Data were collected through surveys, interviews, and visual identity representations. This paper focuses on the literacy stories of two doctoral students with positive literacy identities. Findings suggest that participants valued literacy as a social learning experience from an early age through higher education. These social experiences with reading and writing can take many forms and can be embraced in various home and school contexts. Additionally, these findings highlight the need for schools to create and nurture such experiences across all grade levels, through multiple forums, which may lead to positive literacy identities.
\end{abstract}

\section{INTRODUCTION}

The Scholarship of Teaching and Learning (SoTL) is a valuable approach to advancing teaching and can guide faculty's choices related to pedagogy, curriculum, and other factors involved in student success in higher education (Bender \& Gray, 1999; Gale \& Golde, 2004; Huber \& Robinson, 2016). This helps us to understand how students learn and the instructional practices that support learning. In considering the importance of SoTL, we recognize that new knowledge should be built on what's known as we consider how we can improve teaching and learning through research (Kreber, 2005; McKinney, 2003; Trigwell, 2013; Weimer, 1997). This guides our work with social learning experiences and research on identity.

Social learning has long been a focus of literacy education (Perry, 2012; Street, 1984).This idea supports the notion that students learn with and from others as they bring their personal experiences to their reading and writing. These personal experiences can influence the identity of students and how they "interact, respond, and learn in classrooms" (McCarthey \& Moje, 2002, p. 229). With this in mind, it is important to examine these social learning experiences and how specifically they can impact the identity of learners.

Research has shown that social literacy opportunities have a positive impact on literacy learning (Flint, 2010; Griffin, 2002; Perez, 1998; Schunk, 2012). If literacy identities are socially constructed (Gee, 2012; Moje \& Luke, 2009), and it is our goal as educators to foster positive literacy identities, it is important to examine the social activities that shape positive literacy identities in order to further explore ways in which to provide positive literacy experiences for students.

This study seeks to understand the social literacy learning experiences that two successful doctoral students, with positive literacy identities, value by examining their literacy histories. Using a sociocultural lens, this study was guided by the following question: How do the literacy histories and experiences of doctoral students shape their positive literacy identities? These findings could support higher education instructors in the SoTL process as they work to meet the literacy needs of their students across a range of disciplines. Through this research we hope that professors across institutions can draw on this work to advance teaching and learning
(Felten, 20I3; McKinney, 2003), specifically related to social literacy practices in higher education. Furthermore, by engaging students in social literacy experiences, we can improve the quality of students' academic opportunities. As this study provides information related to the social literacy experiences of doctoral students, professors may use this information to design courses that promote social learning and nurture positive literacy identities.

\section{Theoretical Framework}

The sociocultural perspective views language learning as socially constructed experiences that are part of the cultural context of learners (Lave, 1993;Vygotsky, 1978;Wertsch, 1993). Learning and constructing meaning are social practices (Cook-Gumperz, 1996; Gee, 2012; Wenger, 1999). These theories assert knowledge is constructed through social interactions, with students learning first through social interactions with peers and adults and eventually extending and internalizing knowledge to act independently (Vygotsky, 1978). These theories guided our current study and have also influenced other research on literacy identities (Gee, 2012; Kajee, 2008; McCarthey \& Moje, 2002; Moje \& Luke, 2009). Specifically, the sociocultural framework was used to help examine how doctoral students described their literacy histories, their literacy social experiences and the context in which these experiences occurred. The significance of this study is its contribution to our evolving understanding of literacy identities and how they are socially constructed.

\section{Review of the Literature Identities}

To understand literacy identities we must first define what we mean by identities and literacy. Both identity and literacy have multiple interpretations across different theories and fields of study (Moje \& Luke, 2009). We borrow from Holland and colleagues to define identities as "self-understandings" or the ways in which people "tell themselves and then try to act as though they are who they say they are" (Holland, Lachicotte, Skinner, \& Cain, 1998, p. 3). While identities are enacted by the individual, they are socially constructed. Group membership, social interactions with others, and different contexts shape the identities people take on (McCarthey \& Moje, 
2002).

Identities are multiple, varied across time and context, and constantly in flux (Mishler, 2004). If we return to our definition of identities as "self understandings," consider how these
understandings of oneself change with new experiences as well as shifting understandings of past experiences. Identities are no inherent characteristics of individuals, but rather they are brought to life when recognized by others within relationships or social
contexts. This is important in the teaching and learning process contexts. This is important in the teaching and learning process as we work to build relationships that support
students through social literacy experiences.

\section{Literacy Identities}

We use a sociocultural perspective to conceptualize literacy as a set of social practices (Street, 1984). Literacy is "what people do with reading, writing, and texts in real world contexts and why they do it" (Perry, 2012, p. 54). These literacy practices occur in specific social contexts and are influenced by the historical, cultural,
and power structures within these contexts (Street, 1984). Because and power structures within these contexts (Street, 1984). Because
identities are social constructs, institutions play an active role in identities are social constructs, institutions play an active role in
the development of individual's identity construction (Holland et al., 1998). The home, the community and the school are distinct but of the literacy identities.

Both texts and literacy practices serve as the tools for shaping the literacy identities individuals construct, enact, and explore in various situations (Moje \& Luke, 2009). Moreover, literacy identities influence the texts one chooses to read, write, and discuss in different contexts (McCarthey \& Moje, 2002). The reciprocal relationship between one's identities and one's literacy creating an ever-evolving sense of self as a literate being (Gee, 1996 Kajee, 2008; McCarthey, 2002). Therefore, one's literacy identities can be understood as co-constructed and socially situated selfunderstandings of how one engages in reading, writing, and texts in various contexts and over time. With this in mind, we define positive literacy identities as positive self-understandings and selfperceptions in relation to literacy

Literacy Stories and Representations of Literacy Identities

An individual's sense of self, or identity, can be understoo through stories (McAdams, 1993; McKinney \& Giorgis, 2009) and visual representations (Adams-Budde, Howard, Jolliff, \& Myers,
2014; Bustle, 2004; Georgakopoulou, 2007). Moreover, individuals 2014; Bustle, 2004; Georgakopoulou, 2007). Moreover, individuals
are engaged in the process of identity construction through the telling of these stories and the creation of visual representations. (Bamberg, 2004; Mishler, 2004). Many researchers have used self-reported stories to explore literacy identities of a variety of participants including classroom teachers, literacy specialists, and students (Compton-Lilly, 2013; Drake, Spillane \& HufferdAckles, 2001; McKinney \& Giorgis, 2009). For example, in a study
by Drake et al. (200I) participants shared common stories by Drake et al. (200I) participants shared common stories of
continual literacy development at home and at school that shaped their personal and professional identities as classroom teachers. specialists constructed their identities as writers and teachers of

ps://doi.org/10.20429/ijsotl.2017.110208 writing through interviews and writer autobiographies. In another study, Compton-Lilly (2013) used the stories shared by a student, ermaine, and his mother over a 10-year period to understand how his school literacy experiences shaped his literacy identities as well as his identity as a student. These studies align with and epresenting of identities is a productive means of documenting how identities take shape.

\section{Doctoral Students' Identity Development} Few studies have focused specifically on identity development of doctoral students (e.g., Adams-Budde, Howard, Jolliff, \& Myers, 2014; Hall \& Burns, 2009; Johnson, 2012; Kriner, Coffman,Adkisson, Putman, \& Monaghan, 2015; Noonan, 2015). Both Noonan (2015) and Johnson (2012) report on the findings of self-studies where the researchers examine their own identity development as researcher and scholars while participating in an educational doctoral program. Hall and Burns (2009) use theories of identity to explore the role faculty mentoring plays as educational doctoral thents navigate new identities as scholars. The authors argue that divers dest esearchers. Finally Kriner et al. (2015) found that the students exp in the classroom context and that these experiences provided ints As noted in these studies, a strong scholarly identity can help students find success in doctoral programs. The development of a scholarly identity requires strong literacy identities and skills. While literacy is critical to students' development of scholarly identities, these studies focus only on students' experience while in the program. We believe that students' experiences with literacy throughout their lives (their literacy histories), both at school nd at home, shape their ever-evolving literacy identities. We also (the experiences offer Whe process of their literacy identities construction.

Whic we recognize that there is much research in the areas of identity of doctoral students. Thus, the purpose of this study was 作

\section{METHODS}

This research study uses a case study approach (Yin, 2009) in order to examine how the literacy histories and experiences of doctoral students shaped their literacy identities. Each participant coportunity experacy and interviews.

\section{Participants and Context}

The participants represented in this article are part of a larger study.At the time of the study, the participants were enrolled in the Teacher Education Higher Education (TEHE) Ph.D. program at a four students enrolled in the program were invited to participate. Thirty-six students agreed to participate, and this article represents the case studies of two participants, Eve and Julie (pseudonyms have been used to protect the identity of participants). These two individuals were purposefully selected because their high survey scores revealed that their past literacy experiences impacted
their current, positive literacy identities, and their success and experiences in the Ph.D. program. In addition, these participants were selected because their data captured the themes found across all participants with high literacy survey scores.

Julie was in her third year of the program as a doctoral student focusing on Instructional Technology and Professiona Development. At the time she was working as an Instructiona Technology Facilitator. Julie was a 33 year old, White, female. Prior to enrolling in the doctoral program, she worked as a classroom teacher and instructional coach. Eve was also in her third year as doctoral student with a focus in Student Affairs. She was 35 years old, White, and prior to enrolling in the doctoral program, sh worked as a mental health counselor at a university.

\section{Data Collection}

This study used multiple sources of data (Yin,2009) including survey semi-structured interviews and visual representations created by pasing curret literature on literacy identity (Gee 2006 Mc Cars 2001: Moje \& Luke, 2009). The instrument was shared with reviewers with expertise in literacy and/or identity research and revised based on their feedback in order to increase the content validity. The survey questions were presented to participants the beginning of the study via Qualtrics and served to examin participants' literacy histories and views toward literacy.The survey posed 10 questions, which were answered on a five-point Likert scale ranging from Strongly Disagree (I) to Strongly Agree (5). scale ranging from Strongly Disagree (I) to Strongly Agree (5),
Example survey questions included:I have always enjoyed reading. Growing up, reading and writing were encouraged in my home. Growing up, I was a successful reader and writer.

Participants were selected for the interview process based on high survey scores. The semi-structured interview questions were grounded in literacy identity research (Gee, 2006; McCarthey,
2001; Moje \& Luke, 2009) and sought to explore the relationship 2001; Moje \& Luke, 2009) and sought to explore the relationship between participant's literacy histories and their literacy identities. The interviews ranged from 45 minutes to an hour and provided an opportunity to examine participant's literacy stories. Interview data were audio recorded, and later transcribed. These stories were constructed as they shared and reflected upon their past experiences with reading and writing and how these experiences shaped their current experiences and identities. Example questions included. How would you describe your literacy abilties? Describe literacy pra

The visual representations were created by the participants visual representation includes a range of visual meaning mar. visual representation includes a range of visual meaning making
devices and symbols (Bustle, 2004). This tool (Shephard, 1993) was used as an additional representation of doctoral students' literacy identities.

Each of these data pieces built upon each other, creating layers of data sources. The surveys provided a framework to examine which participants had positive experiences and positive literac dentities. The interview added depth and understanding, telling a story of how and why these identities were formed. Finally, the visual epresentation helped the researchers to view the participants' while building their literacy identities through a different

\section{Data Analysis}

Descriptive statistics were used to analyze the mean scores of the

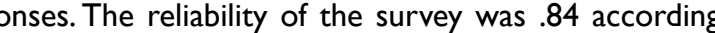
Cronbach's alpha. The qualitative data from the interviews were coded and analyzed using constant comparison analysis (Strauss Corbin, 190). To create a baseline for coding and analysis, the four researchers coded one interview individually. Researchers

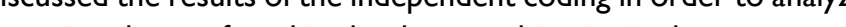
Following found in the data, resulting in six themes.

Following discussion and analysis, the six initial descriptive
nes (Miles \& Huberman 1 1994) were and coded the resining hereach researcher independently read this process, comparis ins were mang the collapsed themes. The related to the social experiences theme is presented.

\section{RESULTS}

Data revealed that doctoral students with strong, confident literacy identities valued the social literacy experiences that served to shape their literacy identities. Additionally, results of the study revealed that participants with positive social literacy experiences programs chose to reflect on their most memorable experiences, which focused on their early and recent experiences with literacy and did not include examples from the middle years of their literacy

ulie

Ulie's positive literacy identities were evident throughout the study. Not only did survey data show Julie as having positive literacy dentities with her mean score as a 4.5 out of 5 , but in her interview, she also characterized herself as a strong, confident reader and writer. Julie also described how she currently felt reading and writing came easily to her and discussed how she had been socially Interview data revealed that Julie's social literacy learning
Inter experiences occurred at an early age. She described how she always emembered her parents reading instead of watching television.Julf

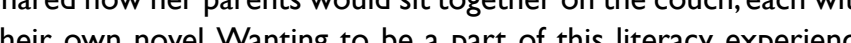
as a young child Julie decided to join in and read with them. These social litercy experiences became the norm for her and her family once she decided to participate in this shared reading time.

As she got older, Julie's social literacy experiences became more formal. While at the time of the study she saw herself as confident, strong, reader and writer, Julie had not always seen
writing as her strong suit. It was not until she had a professor in her undergraduate program that guided her through the writing process with effective feedback and discussion that she began to 
see herself as a writer.Julie began to identify as a writer through this social learning process.Julie also shared how similar discussions and in achieving success as a published author in scholarly publications.
Julie not only appreciated the supportive interactions with her professors, but she valued shared literacy and learning experiences with her peers as well. In the interview Julie stated "The assignments we have when you have to read someone else' work, that's always helpful too because someone else will think of something in a completely different way that I never would have thought of." Julie respected the multiple perspectives of her peers and appreciated the opportunity to give and receive feedback. Additionally, while the class discussion boards were not face-toface social interactions, Julie gained insight from those as well, "The discussion boards where we have to post and comment, I always learn a little bit about different ways to approach a topic or write something. Julie not only enjoyed the social learning provided by discussions in class, but her social learning extended beyon traditional classroom approaches and veered into broader online social forums.

Throughout her interview, Julie discussed her two blogs. She used one blog as an outlet to write about her children and to
share their learning and growing experiences. Her other blog was share their learning and growing experiences. Her other blog was taught in her classroom, staff development, ideas for teachers using technology, etc. Julie shared,

My blog has helped me to get out there too and make some connections with other eductors and teacher educators also do a lot of reading and writing in 140 characters or less. I'm on Twitter a lot with other educators, so I make connections that way as well. I think things like blogs and Twitter that let you put your voice out there... has helped me in the field.

Julie used the Internet as a tool for writing and sharing her knowledge. She also used it as a tool for learning. This social others.

While discussions with her face-to-face and online peers were valued, Julie also had what she called a "critical friend."

I have a critical friend, who reads all $m y$ stuff and gives $m e$ really good feedback. Ive done the same for him... So having a critical friend has really helped and we've also had a couple of things published together. We've read each other's writing so much that it helps our writing style kind of flow better when we try to write something together

Having a critical friend provided Julie with someone who offered support and encouragement as well as constructive feedback fo her confidence as a scholity writer and her literacy iding skills, As previously mentioned participants were asked to creste a

As previously mentioned, participants were asked to create an representation was a sketch of her sitting at her computer desk representation was a sketch of her sitting at her computer desk
with an iPad beside her (see Figure I). This image was another indication of

. she valued sol technology in her social literacy experiences as referenced in her discussion "blogs, Twitter, Google docs." This is another clear indication that Julie's social learning stretched beyond face-to-face interactions and extended into the realm of social media. In the corner of Julie's illustration were two children with books reading together, representing her own children and again showcasing the value she put on social literacy experiences.

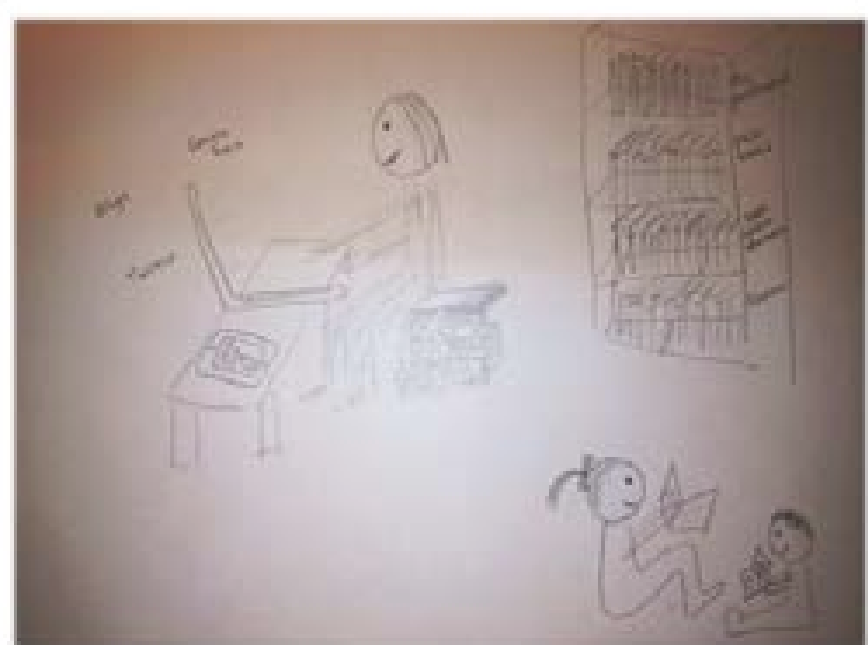

Figure I. Julie's visual representation

\section{Eve}

Eve's positive literacy identities were also showcased in her interview and survey with her mean score as a 4.9 out of 5 . When asked to describe herself as a reader and writer, she described
herself as strong, efficient, organized and concise. Eve attributed her success in literacy to her social learning experiences including feedback from her parents and collaboration with her professors and peers.

Similar to Julie, Eve's interview revealed social learning experiences at an early age. Eve had vivid memories of riding her bike with her sister and friends to the local library. Eve shared, "At the back of the library was the kids section and they had people who would come to read stories for story hour. All of your little friends would do it with you." The visual representation created by
Eve (see Figure 2) represents an extension of these early literacy experiences.

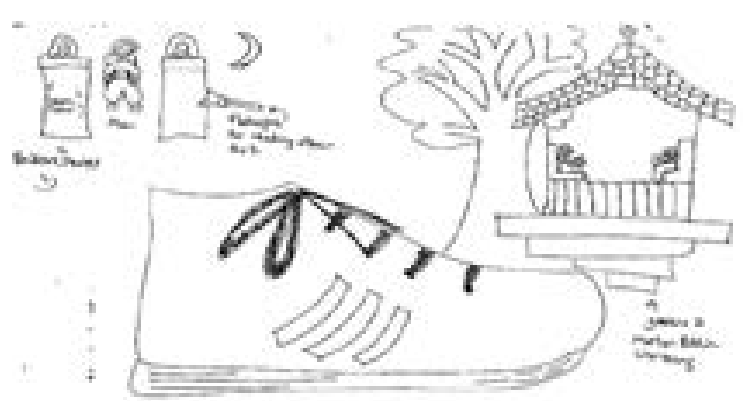

Figure 2. Eve's visual representation

This is my representation of a sneaker, because it was a silver sneaker that the library had, and every time you read a
book the sneaker got moved along the track....Anyway, and book the sneaker got moved along the track.... Anyway, and
then Mom would read to us every night so that was my side of the room and I have a twin sister, Allison and that was hers. Mom would sit in the middle and read to us. We always had a flashlight that you could use to read...And then um, outside the library there was a gazebo and so it would be fun to sit out there and read. There was a huge tree that was behind the gazebo.

All of these experiences described by Eve in her discussion of her visual representation are social literacy experiences. As a child, she valued the opportunity to read with her sister, her mother, and those at the library. Some of these experiences translated into her adult life. Just as Eve read at night before bed with her mother and sister, Eve continued to read at night before bed, "that's what you did when you
were little, so that's what I always do now", she explained. She also discussed that as adults, she and her sister continued to share books, passing them along to each other once they had finished them.

Eve had shared literacy experiences within her family, reading with her sister and mother, and receiving writing feedback from both her parents.

Dad would read my papers before I would turn them in... so he was like your first grade... so it was just cool having the two of them to always go over your writing. As far as writing, my mom would always make us write hand-written thank you notes ever since we could.

These examples represent the idea that in addition to readin writing was a social experience, and one highly valued in Eve' cot with corrcctions "but the end result was it was a ber papers a Her parents provided her feedback on school writing assigm and additionally valued writing as a tool to communicate with the requirement of formal hand-written thank you notes. These socis writing experiences made Eve feel more confident in herself as a writer throughout her schooling.

Literacy as a social experience continued for Eve in higher education. In her interview she discussed collaborating with one of her professors.

I just finished a research project with my professor, so of course we have to write up those findings.... On the paper we just finished, I gave him my litterature] review, he chopped it down to seven pages....at that point you also think everything's important, you know. I just find the more people l've written with, it's gotten much more concise... with my professor now, he's always been a much better writer than me, so l'll always take his feedback.

This example shows that collaboration with professors was important to Eve in her writing process. When asked how her writing had changed since entering the doctoral program, Eve shared, "I think it is more sophisticated than it was... All the feedback l've gotten, that's super feedback, and later she built a relationship with her professor who Provided a a writer to these social literacy experiences.

\section{DISCUSSION}

In considering the importance of literacy as a social experience and examining the literacy experiences through the survey, interview and the visual representations of the participants, it is evident that
both Julie and Eve not only valued social learning, but also attributed these experiences to their success and positive literacy identities. At the time of the study, both participants saw themselves as confident readers and writers. They both have published academic works, including book chapters and articles, which are indicators of strong literacy skills.
It does not come as a surprise that doctoral students have positive literacy identities and literacy histories, however, survey data evealed that some doctoral students did not have positive literacy dentities and histories (Adams-Budde, Howard, Jolliff, \& Myers, 2014). qualities in order to examine how their previous experiences shaped their current positive literacy identities with the hopes of promoting positive self-perceptions and providing these experiences for all Pcudents.

As the participants discussed their literacy histories and dew As the prics ceir social experiences with others. The social interactions that corteres supported by certive process of learning and that discussion helps in negotiating meaning as readers emes across lie and Eve's case studies.

\section{Feedback and Discussion}

Jlie and Eve both discussed the importance of writing with feedback and engaging in discussion as being an important part of their socia lear social literacy learnin Eve valued feedbak, noting that he

Eve valued feedback, noting that her papers often ended up work, and later gave her confidence as a writer. In her interview, Eve discussed how feedback helped her in writing for publication and conference presentations, "I want the comments, and I don't take it personally." Perhaps because of the feedback Eve received growing up, it was easier to accept feedback as a doctoral student to recognize her weaknesses and learn how to turn them into opportunities for improvement.

Julie also shared the important role of feedback in her development as a writer. For Julie, this feedback came from both faceto-face interactions and online discussion boards and social media forums with her peers. Blogging also provided an opportunity for teaching, learning, and sharing ideas outside her immediate context. In addition, Julie's critical friend supported her work through shared reading and writing experiences that not only propelled her positive Iteracy identiles but also served to increase her contributions to the field of literacy and learning through publications. Other researchers have also found peer feedback to be an effective teaching technique in getting graduate students to think more critically about their work as well as gain confidence in 2014; Maher et al., 2008).

\section{Creating Spaces}

Crictions show important pas and current spaces where social literacy was and is important for backround to social action but is socially produced. Meaning whe people do is inflenced by spaces and spaces are shaped by people. For example, Julie remembers sitting on the couch with her parents where they modeled reading, and she now enjoys doing the same with her children. In Eve's case, the past "spaces" she described were at the library where there was a "kid's section" and read aloud opportunities, and at home in her bedroom with her mother and sister at bedtime. Although Eve no longer shares a physical space with her sister, such 
as their bedroom growing up, they continue to talk about and share books with each other

For Julie, the current space of her social literacy learning occurs with her children and through her computer. As an adult Julie's socia literacy learning occurs in both physical and virtual spaces. Rathe than seeing these spaces as separate, researchers such as Leander and and embedded in broader social practices.

\section{MPLICATIONS}

As students are said to construct new knowledge through participation in social practices (Vygotsky, 1978; Wertsch, 1993), it is important to examine how teachers in K-12 classrooms and higher education can Work to integrate social practices as a means of literacy instruction. Because identities are social constructs (Holland et al., 1998) classrooms can play an active role in the development of individual's identity construction. As noted by these participants, their most memorable social literacy experiences were with friends and family at an early age, and much later, in their higher education courses with professors and peers. There is no mention of positive social literacy exel, which begs the question of how to create and nurture these experiences that lead to positive literacy identities throughout sches for studes With this in mind in the field of teacher prepration hisher education, we believe it is essential to provide students with the foundational understanding and corresponding practices so wh they can ensure their own students have opportunities to engage in collaborative learning experiences around reading and writing -

This study has important implications for higher education. The data illustrate the need to provide opportunities for students to use collaboration, communication and discussion of reading and writing to foster a mindset that values the social nature of learning. Research suggests that classroom contexts should foster an multiple perspectives that cause them to think critically about these experiences (Bomer \& Fowler-Amato, 20 I4; Guthrie, 20II).There are several ways instructors can provide opportunities for social learning. One approach is by modeling instruction through a sociocultura lens, the learning that occurs when students engage in authentic and meaningful discussion around reading and writing. In addition, we need to ensure students have experiences in higher education that promote the idea of creating a community of learners (Gambrell, Malloy, \& Mazzoni, 20II), where students feel comfortable taking
academic risks, sharing goals, and providing feedback (lenson, 2013) academic risks, sharing goals, and providing feedback (Jenson, 2013)
which can take place through both face-to-face and online forums.

By understanding the idea that creating spaces does not always
Bathe By understanding the idea that creating spaces does not always
" mean "physical spaces," we can look to Julie's social media and ind online
based social spaces of literacy learning. In face-to-face and on contexts, instructors can support students in creating spaces where they can write collaboratively and have online discussions about their reading and new understandings (McKenna, Labbo, Conradi, \& Baxter, serve to build positive identities for students as readers and writers. While this study focuses on higher education, there are implications for K-12 classrooms.Although participants did not discuss social learning experiences in their elementary school environments,
there is research to suggest social literacy learning experiences are regularly implemented in elementary classrooms (Flint, 2010; Griffin,

ittps://doi.org/10.20429/ijsot.2017.110208
2002; Matthews \& Kesner, 2003; Morrow, Tracey, \& Del Nero, 20I I). However, by the time students reach middle school, there is often a shift to more teacher-centered, direct instruction (Eccles \& Roese 2010; McEwin \& Greene, 2010) with fewer opportunities for socia learning experiences, which is often the result of high stakes testing requirements in the upper grades (McEwin \& Green, 2010; Musolen \& White, 2010). Findings support the idea that it may be beneficial to include more social literacy experiences in middle and secondary classrooms. In K-I2 classrooms, social learning can be nurtured throug the incorporation of activities such as book clubs, where students choose what and how they engage with texts, and perhaps guest readers, similar to what occurred at the library in Eve's experience. Students benefit from collaboration and communication around eracy. When students make sense of what they read and write with others, they are more actively engaged in their learning. Classroom teachers can model and support literacy rich environments with the creation of "kids spaces" as mentioned in Eve's interview, where there is comfortable furniture or outdoor spaces where students can read and write. These spaces can be created across grade levels from elemenary to secondary classrooms, and may serve to show shared, positive, literacy experiences can take place anywhere.

\section{LIMITATIONS AND FUTURE RESEARCH}

This study provides clear examples of the importance of literacy as a social experience. However, while reflecting and critically evaluating our research process, we identified several limitations. This study represents a small sample of doctoral students in one program at one university and the participants are not diverse in terms of race or gender. These limitations lead to opportunities for future research. For example, using a SoTL lens, we could recruit participants across the various intinney,2003) from diverse backgrounds. Understanding to be beneficial because having multiple perspectives may provide understanding into how diverse groups define literacy and engage in literacy throughout their lives. In addition, these perspectives may provide insight into the types of literacies that are valued in various contexts. Despite these limitations and opportunities for future research, this study addresses a gap in the literature that focuses on the combined fields of literacy and identity by linking them to success with doctoral students. This study underscores the nee for educational institutions to examine doctoral students' literacy experiences therefore contributing to the Scholarship of Teachin and Learning.

\section{CONCLUSION}

This study shows how higher education programs can focus on the teaching and learning process in ways that engage students an is a gre their literacy identites. Kreber (2005) argues that there "the kinds of learning experiences we hope students will have during their college and university years and why we believe certave during their college and university years, and why we believe certain
experiences are more valuable than others" (p. 391). This study provides insight into those learning experiences we want to provide for students. Specifically, the strategies discussed by these participants could be implemented across higher education programs including personalized feedback from professors, writing opportunities with professors and peers and social learning opportunities in online spaces. Not only is the implementation of these practices important but the valuing of student reading and writing within these practices is important. With positive literacy identities, students feel more
confident in their abilities to read and write and find success in schoo programs. If we wish to nurture positive literacy experiences as literacy community, it may benefit us to promote more authentic social literacy learning opportunities in higher education classrooms that will serve to enhance the positive literacy identities of students including those who may one day pursue their doctoral degree. This article provides insight into experiences doctoral students found to be beneficial. These experiences may not look the same across all students. Therefore, university instructors need to be able to value the expeniences of all students as they contrue to explore instruction decisions that positively shape students' literacy identities.

\section{REFERENCES}

Adams-Budde, M., Howard, C., Jolliff, G., \& Myers, J. (2014). Examinin the literacy histories of doctoral students in an educational studies program through surveys and interviews: A mixed methods study. Journal of the Scholarship of Teaching and Learning,
14, 109-125.

Bamberg, M. (2004). Form and functions of 'slut bashing' in male identity constructions in 15-year-olds. Human Development, 47(6). $331-353$.

Bender, E. \& Gray, G (1999). The scholarship of teaching. Research \& Creative Activity, 22(I). Retrieved from http://www.indiana. \& Creative Activity, $22(1)$. Ret

Bernadowski, C. \& Aspinall, J. (2014). An evaluation of peer review in courses. International Forum, I7(2), 44-57. Building upon youths' practices, purposes, rolescent writing thoughtfulness. In K.A. Hinchman \& H.K. Sheridan-Thomas (Eds). Best practices in adolescent literacy instruction (2nd ed., pp. 154-

Bustle, L. (2004). The role of visual representation in the assessmen of learning.Journal of Adolescent and Adult Literacy, 47(5), 416-423.

Compton-Lilly, C. F. (2013). The temporal expectations of schooling and literacy learning:Jermaine's story.Journal of Adolescent \& Adul Literacy, 56(5), 400-408.

Cook-Gumperz,J.(1996). The social construction of literacy. Cambridge, UK: Cambridge University Press.

Drake, C., Spillane, J. P., \& Hufferd-Ackles, K. (200I). Storied identities: Teacher learning and
Studies, 33(I), I-23.

Eccles, J. S., \& Roeser, R.W, (2010). An ecological view of schools and development. In J. Meece \& J.S. Eccles (Eds.), Hando-o of p. 6-2I). New York NY: Routledge.

Felten, P. (2013). Principles of good practice in SoTL. Teaching and

Flint T. K. (2010). Making meaning together: Buddy reading in a fist grade classroom. Early Childhood Education Journal 38. 289-297. Gale, R. \& Golde, C.M. (2004). Doctoral education and the scholarsh of teaching and learning. Peer Review, 6(3), 8- 12.

Gambrell, L.B., Malloy,J.A., \& Mazzoni, S.A. (201I). Evidence-based best practices in comprehensive literacy instruction. In L.M. Morrow Pp. ( I-36). New York, NY:The Guilford Press.
,.P. (1996). Sociolinguistics and literacies: Ideology in discourses (2nd ed.). London, UK: Taylor \& Francis

ee, J.P. (2006). Self-fashioning and shape-shifting: Language, identity and social class. In D.E.Alvermann, K.A. Hinchman, D.W. Moore, S. F. Phelps, \& D.W. Raff (Eds.). Re

Mahwah, NJ: Erlbaum.

. J.P. (2012). Social linguistics and literacies: Ideology in discourses (4th ed.) New York, NY: Routledge.

(V) 8). Philadelphia, PA: John Benjamins Publishing

riffin, M.L. (2002). Why don't you use your finger first grade. The Reading Teacher, 55(8), 766-774.

for In L.M. Morrow \& L.B. Gambrell (Eds). Best practices in literacy instruction (4th ed., Pp. 177-198). New York, NY: The Guilford

in ., \& Burns, L. D. (2009). Identity development and mentoring in doctoral education. Harvard Educational Review, 79(I), 49-70.

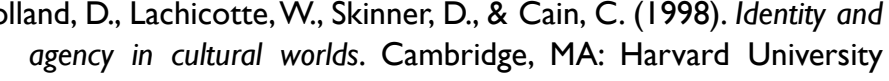
agency
Press.

Huber. M.T. \& Robinson, J.M. (2016). Mapping advocacy and outreach for the scholarship of teaching and learning. Teaching \& Learning Inquiry, 4(I), I-4.

Jen $E$. (2013). Engaging students with poverty in mind: Procticel strategies for raising achievement. Alexandria, VA: ASCD.

sto. literacy researcher. English Teaching: Practice and Critique, II(2). $81-93$

A. (2008). Constructing identities in online communities of practice: A case study of online learning. Bern, Switzerland: Peter Lang.

A cer, (2005). Charting a critical course on the scholarship of university

作, B.A., Coffman, K.A.,Adkisson,A. C., Putman, P. G., \& Monaghan, C. H. (2015). From students to scholars: The transformativ power of communities of practice. Adult Learning 26(2), 73-80.

Lave, J., (1993). Situated learning in communities of practice. In $\mathrm{L}$. B. Resnick, J. M. Levine, \& S. D. Teasley (Eds.), Perspectives on socially shared cognition (Pp. 17-36). Washington, DC: American Psychological Association

Leander, K. M., \& McKim, K. K. (2003). Tracing the everyday 'sittings' of adolescents on the Internet: A strategic adaptation of ethnography across online and offline spaces. Education, Communication, \&

(Vol. 142). Blackwell:

Oxford.
(200), Seaton, L., McMullen, C., Fitzgerald, T., Otsuji, E., \& Lee A. (2008). Becoming and being writers:The experiences of doctoral students in writing groups. Studies in Continuing Education, 30(3), students in $263-275$.

Matthews, M.W., \& Kesner,J. (2003). Children learning with peers: The confluence of peer status and literacy competence within smallgroup literacy events. Reading Research Quarterly, $38(2) 208-234$
Adams, D. P. (1993). The stories we live by: Personal myths and the making of the self. New York: Morrow.

McCarthey,S.).(2001).Identity construction in elementary readers and 
writers. Reading Research Quarterly, 36(2), I22-I5I.

McCarthey, S. J. (2002). Students' identities and literacy learning. Newark: DE: International Reading Association.

McCarthey, S. J., \& Moje, E. B. (2002). Identity matters. Reading Research Quarterly, 37(2), 228238.

McEwin, C., \& Greene, M. (2010). Results and recommendations from the 2009 national surveys of randomly selected and highly successful middle level schools. Middle School Journal, 42(I), 49-63.

McKenna, M.C., Labbo, L.D., Conradi, K., \& Baxter, J. (20I I). Effective uses of technology in literacy instruction. In L.M. Morrow \& L.B. Gambrell (Eds). Best practices in literacy instruction (4th ed., pp. 36I-394). New York, NY:The Guilford Press.

McKinney, K. (2003). Applying the scholarship of teaching and learning: How can we do better? The Teaching Professor, 1,5,8.

McKinney, M., \& Giorgis, C. (2009). Narrating and performing identity: Literacy specialists' writing identities. Journal of Literacy Research, $4 I(I), 104-149$.

Miles, M., \& Huberman,A. (1994). Qualitative data analysis:A sourcebook of new methods. Thousand Oaks, CA: Sage.

Mishler, E.G. (2004). Historians of the self: Restorying lives, revising identities. Research in Human Development, I(I), I0I-I 2 I.

Moje, E. B., \& Luke, A. (2009). Literacy and identity: Examining the metaphors in history and contemporary research. Reading Research Quarterly, 44(4), 4I5-437.

Morrow, L. M., Tracey, D. H., \& Del Nero, J. R. (20I I). Best practices in early literacy: Preschool, kindergarten, and first grade. In L.M. Morrow \& L.B. Gambrell (Eds). Best practices in literacy instruction (4th ed., pp. 67-95). New York, NY:The Guilford Press.

Musoleno, R. R, \& White, G. P. (20I0). Influences of high-stakes testing on middle school mission and practice. Research in Middle Level Education, 34(3), I- 10.

Noonan, S. J. (20I5). Doctoral pedagogy in stage one: Forming a scholarly identity. International Journal of Education Leadership Preparation, 10(1), 2-28.

Perez, B. (1998). Sociocultural contexts of language and literacy. Mahwah, $\mathrm{NJ}$ : Erlbaum.

Perry, K. H. (20/2). What is literacy? - A critical overview of sociocultural perspectives. Journal of Language and Literacy Education, 8(I), 50-7I.

Schunk, D. H. (20I2). Learning theories: An educational perspective (6th ed.). Boston, MA: Pearson.

Shepard,R.(1993). Elementary media education:The perfect curriculum. English Quarterly, 25, 35-38.

Strauss, A., \& Corbin, J. (1990). Basics of qualitative research: Grounded theory procedures and techniques. London, UK: Sage.

Street, B. V. (1984). Literacy in theory and practice. Cambridge, UK: Cambridge University Press.

Trigwell, K. (20I3). Evidence of the impact of the scholarship of teaching and learning purposes. Teaching \& Learning Inquiry, I(I). 95-105.

Vygotsky, L. S. (1978). Mind in society: The development of higher psychological processes. Cambridge, MA: Harvard University Press.

Weimer, M. (1997). Integration of teaching and research: Myth, reality, and possibility. New Directions for Teaching and Learning, 72, 53-62.

Wenger, E. (1999). Communities of practice: Learning, meaning, and identity. New York, NY: Cambridge University Press.

Wertsch, J. V. (1993). Voices of the mind: A sociocultural approach to mediated action. Cambridge, MA: Harvard University Press.

West, K. C. (2008). Weblogs and literary response: Socially situated identities and hybrid social languages in English class blogs. Journal of Adolescent and Adult Literacy, 5 I (7), 588-598.

Witte, S. (2007). "That's online writing, not boring school writing": Writing with blogs and the Talkback Project. Journal of Adolescent and Adult Literacy, 5 I (2), 92-96.

Yin, R. K. (2009). Case study research design and methods. Thousand Oaks, CA: Sage. 